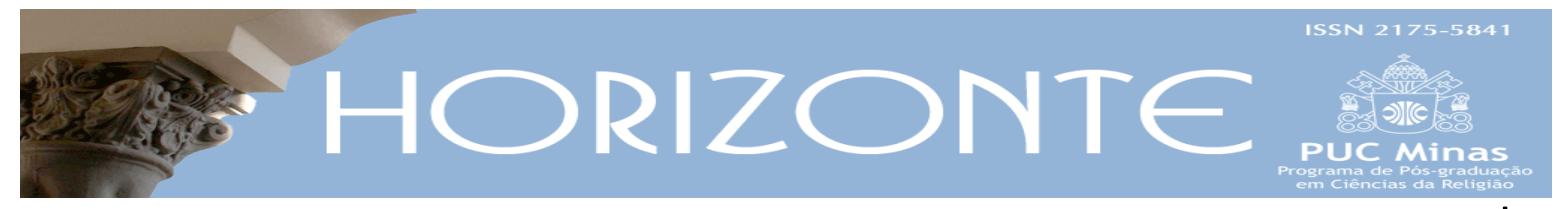

Resenha

DOI - 10.5752/P.2175-5841.2015v13n39p1709

\title{
OSBORNE, Grant R. Apocalipse: comentário exegético. São Paulo: Vida Nova, 2014. 999p. ISBN 978-85-275-0562-8.
}

Ângelo Vieira da Silva*

Há muitos cristãos ávidos por conhecimento profundo acerca dos livros que compõem o seu texto sagrado. Infelizmente, em virtude do obstáculo do idioma, muitos ainda não têm acesso ao vasto e valioso material exegético que pode ser encontrado em outros países. Nesse sentido, pode-se concordar que existem poucas obras proeminentes no vernáculo, isto é, com profundidade semelhante ou superior as de muitos livros estrangeiros. Grande parte do que se vê - ou se lê refere-se a publicações rasas, compêndios ou agrupamento de outras obras, o que limita o conhecimento de muitos daqueles cristãos que buscam uma instrução sólida. Por isso, a edição de um novo comentário exegético em português atrai consideração e, espera-se, "novos céus e nova terra" na publicação de obras relevantes em português.

O livro Apocalipse: Comentário Exegético é uma obra de pesquisa minuciosa de Grant R. Osborne, erudito Doutor pela Universidade de Aberdeen (Reino Unido), especialista em hermenêutica bíblica (conhecido pelo conceito da espiral hermenêutica' ${ }^{1}$ e professor de Novo Testamento no Trinity Evangelical Divinity School (Estados Unidos). Além da análise acadêmica do texto do último

\footnotetext{
Resenha recebida em 08 de julho de 2015 e aprovada em 18 de setembro de 2015. Mestre em Ciências da Religião.

* Mestre em Ciências da Religião e Bacharel em Teologia. País de origen: Brasil. E-mail: revavds@gmail.com.

${ }^{1}$ Mais detalhes desse conceito são encontrados na obra de OSBORNE, Grant R. Espiral Hermenêutica: uma nova abordagem à interpretação bíblica. São Paulo: Vida Nova, 2009.
} 
livro da Bíblia cristã, a obra se destaca na preocupação com o simbolismo apocalíptico aliado ao debate em torno das principais escolas de interpretação (historicista, preterista, idealista e futurista).

Após uma introdução exegética (exames de autoria, data, contextos, gêneros literários, propósito, teologia, métodos de interpretação do livro, etc), a extensa obra é dividida em seis capítulos, considerando como unidades (a) o prólogo de João nos oito versículos iniciais, (b) a visão posterior seguida das cartas às sete igrejas da Ásia Menor, (c) a apresentação do soberano Deus e o conflito com o mal, (d) a descrição do juízo final na chegada do eschaton, (e) o novo céu e nova terra na figura da nova Jerusalém e (f) o epílogo da revelação. Ademais, também há um duplo prefácio que destaca a boa fundamentação do livro de Osborne, repleta de dados relevantes à pesquisa bíblica.

O primeiro capítulo estabelece uma unidade literária de Apocalipse 1.1-8. A partir do desenvolvimento de tradições proféticas e epistolares helenísticas, Osborne destaca o processo de inicialização da Revelação definindo termos que envolvem título, saudação e doxologia cujo propósito é apresentar muitos dos principais temas a serem tratados no Apocalipse.

O segundo capítulo aborda outra unidade literária, configurada por Apocalipse 1.9 a Apocalipse 3.22. A partir da primeira visão do livro atribuído a João, acerca do Jesus Cristo glorificado, o autor volta-se para as mensagens dirigidas inicialmente às sete igrejas indicadas: Éfeso, Esmirna, Pérgamo, Tiatira, Sardes, Filadélfia e Laodicéia. A partir da fórmula êxito-fracasso ("conheço tuas obras" e "tenho contra ti”), Osborne defende o caráter circular das cartas em uma estrutura de sete partes que as equilibram.

A terceira unidade literária engloba Apocalipse 4.1 a Apocalipse 16.21. Osborne a vê como uma terceira seção introdutória que prepara o leitor para a seção principal do livro, aquela que se refere aos selos, às trombetas e às taças. Nesse contexto, o autor destaca que o grande conflito entre Deus e as forças do mal 
redundará na glória do primeiro e no juízo do segundo. Considerando o "trono" como o tema unificador dos capítulos da terceira unidade, e à luz dos profetas Isaías e Ezequiel, Osborne estipula os fundamentos da adoração litúrgica, bem como enaltece a majestade e soberania daquele que se assenta no trono.

A quarta parte descreve Apocalipse 17.1 a Apocalipse 20.15, constituindo outra unidade literária, após a conclusão da visão dos selos, trombetas e taças da ira. Tendo em conta a análise do discurso e o conteúdo do rolo do manuscrito, o autor estabelece que o juízo descrito na unidade é uma expansão literária do quadro da sétima taça, cheia da ira divina, dada à grande Babilônia. O juízo é chegado para a cidade do mal, para os ímpios, para o dragão e suas bestas, que são acompanhados pela morte e pelo hades, encerrando-se, assim, a unidade proposta por Osborne em torno do tema da punição eterna como tema gerador.

O capítulo cinco define a próxima unidade literária: Apocalipse 21.1 a Apocalipse 22.5. Devido ao forte tom exortativo, o autor subscreve a seção como um parágrafo dramático, a despeito das visões da cidade santa e do novo Éden. Assim, Osborne expõe a passagem como uma ligação da realidade celestial à terrena que, ao final, se tornam uma. Eis uma nova ordem celestial, a nova Jerusalém. Eis o Éden transformado, cheio de vida.

A última unidade literária refere-se ao desfecho da revelação, ao complexo epílogo de Apocalipse 22.6-21. As declarações finais do Apocalipse tanto advertem como encorajam, tanto são para justos como para ímpios. Por outro lado, é evidente na conclusão a validação e autenticidade da profecia, a necessidade da conversão dos descrentes e perseverança dos crentes, bem como a certeza do retorno próximo de Jesus Cristo.

Finalmente, necessário é criticar tal obra. Um comentário acadêmico de peso? Erudição aliada a estilo claro e acessível? Sim. Eis uma obra confiável, repleta de úteis detalhes exegéticos e intertextuais. A dinâmica na apresentação do texto bíblico a partir de uma unidade literária (um bloco de parágrafo ou perícope 
bem maiores que o convencional) favorece muito a compreensão teológica da revelação. Do mesmo modo, os índices de assuntos e palavras gregas que recheiam as últimas páginas do livro são ferramentas didáticas essenciais nesta acadêmica obra de Osborne que, de fato, pode revelar "seu interesse vital pelas necessidades práticas de estudantes, [líderes] e leigos”.

As notas adicionais ao final de cada unidade possuem certamente grande valor acadêmico. Entretanto, sua leitura seria mais facilitada se fossem apresentadas em rodapé, próximas do texto bíblico ou dos comentários de Osborne a que se referem. Tratando-se de um livro extenso, as constantes idas e vindas à procura das notas, em vista de compreender detalhes apenas indicados pelo comentário de Osborne, acabam por tornar a tarefa pouco estimulante.

Limites à parte, vale destacar, isto sim, que “a interpretação é o cerne da questão”. Daí a compreensão de que Apocalipse: Comentário Exegético pode ser lido como um trabalho minucioso relativo "aos últimos dias”. Entenda-se a última expressão entre aspas. Osborne labutou no exame do texto apocalíptico associando-o ora ao presente, ora ao passado, ora ao futuro. Entre preterismo, historicismo e futurismo, com alguns traços de idealismo, o autor propõe que o último livro da Bíblia cristã descreve fatos já consumados e outros ainda para se concretizar; postulou, igualmente, seu valor espiritual. Conforme o exame de Osborne, a riqueza de possibilidades de leitura a que se abre o Apocalipse bíblico pede que não se estabeleça para esse livro um método único de interpretação, mas que se evidencie o caráter pleno e multifacetário da profecia apocalíptica no tempo. Talvez, seja isso que Osborne quis dizer com a expressão "hermenêutica da humildade". Tudo isso faz dessa obra um comentário exegético de grande alcance e valor para os dias atuais. 